\title{
Nutrition, dietary interventions and prostate cancer: the latest evidence
}

\author{
Pao-Hwa Lin ${ }^{1 *}$, William Aronson ${ }^{2,3}$ and Stephen J Freedland ${ }^{4,5}$
}

\begin{abstract}
Prostate cancer ( $\mathrm{PCa}$ ) remains a leading cause of mortality in US men and the prevalence continues to rise world-wide especially in countries where men consume a 'Western-style' diet. Epidemiologic, preclinical and clinical studies suggest a potential role for dietary intake on the incidence and progression of PCa. 'This minireview provides an overview of recent published literature with regard to nutrients, dietary factors, dietary patterns and PCa incidence and progression. Low carbohydrates intake, soy protein, omega-3 (w-3) fat, green teas, tomatoes and tomato products and zyflamend showed promise in reducing PCa risk or progression. A higher saturated fat intake and a higher $\beta$-carotene status may increase risk. A ' $U$ ' shape relationship may exist between folate, vitamin C, vitamin D and calcium with PCa risk. Despite the inconsistent and inconclusive findings, the potential for a role of dietary intake for the prevention and treatment of PCa is promising. The combination of all the beneficial factors for PCa risk reduction in a healthy dietary pattern may be the best dietary advice. This pattern includes rich fruits and vegetables, reduced refined carbohydrates, total and saturated fats, and reduced cooked meats. Further carefully designed prospective trials are warranted.
\end{abstract}

Keywords: Diet, Prostate cancer, Nutrients, Dietary pattern, Lifestyle, Prevention, Treatment, Nutrition, Dietary intervention, Review

\section{Introduction}

Prostate cancer $(\mathrm{PCa})$ is the second most common cancer in men, with nearly a million new cases diagnosed worldwide per year [1], with approximately a six-fold higher incidence in Western than in non-Western countries. Diet, lifestyle, environmental and genetic factors are hypothesized to play a role in these differences. This review focuses on the latest evidence of the potential role of dietary factors on $\mathrm{PCa}$ and includes epidemiologic and clinical trial evidence for the impact of protein, fat, carbohydrate, fiber, phytochemicals, other food components, whole foods and dietary patterns on PCa incidence, development and/or progression.

Data from meta-analyses or well-designed randomized trials and prospective studies are emphasized in this review. It should be noted that studies of dietary intake or nutrition and cancer are often subject to various limitations and thus complicate interpretation of results. For example, when a study is designed to examine the effect

\footnotetext{
* Correspondence: pao.hwa.lin@dm.duke.edu

'Department of Medicine, Division of Nephrology, Duke University Medical Center, Box 3487, Durham, NC 27710, USA

Full list of author information is available at the end of the article
}

of the amount of fat intake, alteration in fat intake inevitably will change intake of protein and/or carbohydrate, and may change the intake of other nutrients as well. As a result, it is difficult to attribute the effect to change in fat intake alone. In addition, the impact of macronutrients potentially involves aspects of both absolute quantity and the type of macronutrients consumed. Both aspects may potentially affect cancer initiation and/or development independently, but they are not always distinguishable in research designs. Though this topic was recently reviewed [2], given the extensive new literature on the topic, an updated review is presented herein and a summary table is provided for a quick reference (Table 1).

\section{Nutrients \\ Carbohydrates}

Given the hypothesis that insulin is a growth factor for $\mathrm{PCa}$, it has been hypothesized that reducing carbohydrates and thus lowering serum insulin may slow PCa growth [3]. Indeed, in animal models, either a no-carbohydrate ketogenic diet (NCKD) $[4,5]$ or a low-carbohydrate diet (20\% kcal as carbohydrate) has favorable effects on slowing prostate tumor growth [6,7]. In human studies, one 
Table 1 Summary of nutrients and food factors with prostate cancer

\begin{tabular}{|c|c|c|c|c|}
\hline $\begin{array}{l}\text { Nutrient or food factor } \\
\text { and references }\end{array}$ & Preclinical study & Epidemiological study & Clinical study & Summary \\
\hline Carbohydrate $[3-7]$ & Low carbohydrate slowed tumor growth. & Rare & On-going & Potential, awaits evidence from RCT \\
\hline Protein [23-46] & $\begin{array}{l}\text { Soy protein slowed tumor progression. } \\
\text { Genistein inhibited PCa cell detachment, } \\
\text { invasion, and metastasis. }\end{array}$ & $\begin{array}{l}\text { Mixed results in total protein, dairy, soy } \\
\text { intake. }\end{array}$ & $\begin{array}{l}\text { Supplement of geneistein reduced PCa } \\
\text { progression. }\end{array}$ & $\begin{array}{l}\text { Soy products showed potential benefit, } \\
\text { need more RCT to confirm. }\end{array}$ \\
\hline Fat [47-84] & $\begin{array}{l}\text { Low fat reduced PCa risk, high fat } \\
\text { increased risk. }\end{array}$ & $\begin{array}{l}\text { Mixed results. Saturated fat may increase } \\
\text { and plant fat decrease PCa risk. W-3 PUFA } \\
\text { may decrease risk. }\end{array}$ & $\begin{array}{l}\text { Low fat plus } W-3 \text { PUFA reduced PCa pro- } \\
\text { liferation and CCP. }\end{array}$ & $\begin{array}{l}\text { Further research needed to clarify role of } \\
\text { amount and type of total fat and fatty } \\
\text { acids. }\end{array}$ \\
\hline Vitamin A [85-90] & NA & $\begin{array}{l}\text { Higher serum } \beta \text {-carotene associated with } \\
\text { higher PCa risk. }\end{array}$ & $\begin{array}{l}\beta \text {-carotene supplement increased PCa } \\
\text { risk. }\end{array}$ & Supplement not advised. \\
\hline Folate [91-98] & Folate depletion reduced tumor growth. & $\begin{array}{l}\text { Higher circulation folate associated with } \\
\text { higher PCa risk or lower PSA. }\end{array}$ & $\begin{array}{l}\text { Supplement folate had no effect on PCa } \\
\text { risk. }\end{array}$ & $\begin{array}{l}\text { Potential dual role of folate in prostate } \\
\text { carcinogenesis, needs further } \\
\text { examination. }\end{array}$ \\
\hline Vitamin C [89] & $\begin{array}{l}\text { May slow tumor growth in vitro and } \\
\text { in vivo. }\end{array}$ & Rare & Rare. One study showed no effect. & $\begin{array}{l}\text { May act both as pro-oxidant and } \\
\text { antioxidant. Needs clarification. }\end{array}$ \\
\hline Vitamin D [100-114] & May slow PCa progression. & $\begin{array}{l}\text { Serum vitamin D associated with a higher } \\
\text { or lower risk. }\end{array}$ & $\begin{array}{l}\text { No impact of vitamin D supplement on } \\
\text { PSA or PCa risk. }\end{array}$ & $\begin{array}{l}\text { A ' } U \text { ' shaped relationship may exist } \\
\text { between vitamin } D \text { status and } P C a \text {. }\end{array}$ \\
\hline Vitamin E [115-125] & May slow PCa tumor growth. & $\begin{array}{l}\text { Some show no association between } \\
\text { vitamin E supplement and PCa risk. }\end{array}$ & $\begin{array}{l}400 \mathrm{IU} \text { supplement had no effect or } \\
\text { increased PCa risk, but } 75 \text { IU supplement } \\
\text { lowered risk. }\end{array}$ & $\begin{array}{l}\text { Weak evidence of benefit, further } \\
\text { research should consider dosage also. }\end{array}$ \\
\hline Vitamin K $[126,127]$ & $\begin{array}{l}\text { Anti-tumor, chemo and potential } \\
\text { radiosensitizers. }\end{array}$ & $\begin{array}{l}\text { Inverse relationship between vitamin } \mathrm{K} \\
\text { and PCa incidence. }\end{array}$ & NA & Inadequate evidence \\
\hline Calcium [128-130] & Rare & $\begin{array}{l}\text { Calcium intake increased or decreased } \\
\text { PCa risk. }\end{array}$ & A ' $U$ ' shaped relationship may exist. & $\begin{array}{l}\text { Further research is needed to clarify if } \\
\text { any association exists. }\end{array}$ \\
\hline $\begin{array}{l}\text { Selenium } \\
{[123,125,131,132]}\end{array}$ & $\begin{array}{l}\text { Inhibit angiogenesis, proliferation, } \\
\text { inducing apoptosis. }\end{array}$ & $\begin{array}{l}\text { Toenail selenium associated with reduced } \\
\text { advanced PCa risk. }\end{array}$ & $\begin{array}{l}\text { Selenium supplement had no effect for } \\
\text { PCa chemoprevention, or increased high } \\
\text { grade PCa risk among men with high } \\
\text { selenium status. }\end{array}$ & $\begin{array}{l}\text { Conflicting results, more research is } \\
\text { needed. }\end{array}$ \\
\hline Silibinin [133-135] & $\begin{array}{l}\text { Inhibit PCa growth via EGFR, IGF-1R, } \\
\text { NF-kB, TGF } \beta 2 \text {, and CAF-like markers. }\end{array}$ & NA & NA & $\begin{array}{l}\text { Potential as chemopreventive agent, } \\
\text { awaits further research. }\end{array}$ \\
\hline Curcumin $[136,137]$ & $\begin{array}{l}\text { Inhibited proinflammatory NF-B, induced } \\
\text { apoptosis, slowed PCa growth. }\end{array}$ & NA & NA & $\begin{array}{l}\text { Potential to slow PCa growth, awaits } \\
\text { further research. }\end{array}$ \\
\hline Pomegranate [137-141] & Inhibited PCa proliferation, angiogenesis. & & $\begin{array}{l}\text { Pomegranate juice increased PSA } \\
\text { doubling time in one trial, but no } \\
\text { controls included. Another trial showed } \\
\text { no impact. }\end{array}$ & Weak evidence of benefit. \\
\hline $\begin{array}{l}\text { Green tea } \\
{[131,137,142-145]}\end{array}$ & $\begin{array}{l}\text { Inhibited PCa growth, induced apoptosis, } \\
\text { decreased inflammation. }\end{array}$ & NA & $\begin{array}{l}\text { Green tea catechin or EGCG supplement } \\
\text { reduced PCa incidence or PSA. }\end{array}$ & $\begin{array}{l}\text { Some evidence of benefit, more research } \\
\text { needed. }\end{array}$ \\
\hline Resveratrol [137,146-151] & $\begin{array}{l}\text { Inhibited PCa growth in some but not all } \\
\text { studies. }\end{array}$ & NA & NA & Potential, awaits further study. \\
\hline Zyflamend [152-157] & Reduced PCa progression. & NA & $\begin{array}{l}\text { Reduced risk among those with high } \\
\text { grade PCa. }\end{array}$ & Potential to slow PCa growth. \\
\hline
\end{tabular}


Table 1 Summary of nutrients and food factors with prostate cancer (Continued)

\begin{tabular}{|c|c|c|c|c|}
\hline $\begin{array}{l}\text { Fruits and vegetables } \\
\text { [158-163] }\end{array}$ & Allium vegetable reduced PCa risk. & $\begin{array}{l}\text { Inverse relationship between total fruit } \\
\text { and vegetable intake and PCa risk. }\end{array}$ & $\begin{array}{l}\text { Supplement of pomegranate, green tea, } \\
\text { broccoli, turmeric reduced PSA rise. }\end{array}$ & $\begin{array}{l}\text { Moderate evidence, consistent with } \\
\text { current dietary guideline to encourage } \\
\text { rich intake. }\end{array}$ \\
\hline $\begin{array}{l}\text { Tomatoes and products } \\
{[131,164-176]}\end{array}$ & $\begin{array}{l}\text { Lycopene slowed PCa growth, } \\
\text { progression. }\end{array}$ & $\begin{array}{l}\text { Higher lycopene intake or serum level } \\
\text { associated with lower PCa risk in some } \\
\text { studies. }\end{array}$ & $\begin{array}{l}\text { Supplement lycopene lowered PSA, PCa } \\
\text { symptoms in some studies. }\end{array}$ & $\begin{array}{l}\text { Moderate evidence, needs large RCT to } \\
\text { confirm. }\end{array}$ \\
\hline Coffee [177-183] & NA & $\begin{array}{l}\text { Inverse between coffee consumption and } \\
\text { PCa risk in some studies but not all. }\end{array}$ & NA & Potential benefit. \\
\hline $\begin{array}{l}\text { Dietary pattern } \\
\text { [70,184-191] }\end{array}$ & NA & $\begin{array}{l}\text { High HEI associated with lower PCa risk. } \\
\text { Mediterranean diet may prevent PCa. } \\
\text { Western diet associated with higher PCa } \\
\text { risk and Asian diet opposite. }\end{array}$ & NA & Promising. RCT needed. \\
\hline
\end{tabular}

CAF, cancer-associated fibroblasts; CCP, cell cycle progression; EGCG, epigallocatechin gallate; EGFR, epidermal growth factor receptor; HEl, Healthy Eating Index; IGF-1R, IGF1 receptor; NF-kB, nuclear factor kappa B; PCa, prostate cancer; PA, prostate specific antigen; PUFA, polyunsaturated fatty acid; RCT, randomized controlled trial; TGF $\beta 2$, transforming growth factor $\beta 2$. 
study found that high intake of refined carbohydrates was associated with increased risk of PCa [7]. In addition to the amount of carbohydrates, type of carbohydrates may impact on PCa but research has been inconclusive.

The potential to reduce PCa risk and progression via impacting carbohydrate metabolism is actively being investigated with Metformin. Metformin reduced PCa cell proliferation and delayed progression in vitro and in vivo, respectively [8-10] and reduced incident risk and mortality in humans [11-13]. Two single arm clinical trials also showed a positive effect of metformin in affecting markers of PCa proliferation and progression [14,15]. However, other retrospective cohort studies have not supported an effect of metformin on recurrence or incident risk of PCa [16-22].

Despite the potential for reducing either total or simple carbohydrates in benefiting PCa control, evidence is lacking from randomized controlled trials (RCT). Two randomized trials are on-going examining the impact of a low-carbohydrate diet (approximately $5 \% \mathrm{kcal}$ ) on the PSA doubling time among PCa patients post radical prostatectomy (NCT01763944) and on glycemic response among patients initiating androgen deprivation therapy (ADT) (NCT00932672 ). Findings from these trials will shed light on the effect of carbohydrate intake on markers of PCa progression and the role of reduced carbohydrate intake on offsetting the side effects of ADT.

\section{Protein}

The ideal level of protein intake for optimal overall health or prostate health is unclear. Despite the popularity of low carbohydrate diets that are high in protein, recent human studies reported that low protein intake was associated with lower risk for cancer and overall mortality among men 65 and younger. Among men older than 65, low protein intake was associated with a higher risk for cancer and overall mortality [23]. In animal models the ratio between protein and carbohydrate impacted on cardiometabolic health, aging and longevity [24]. The role of dietary protein and the protein to carbohydrate ratio on PCa development and progression requires further study.

\section{Animal-based proteins}

Studying protein intake, like all aspects of nutritional science, can be challenging. For example, animal meat, which is a source of protein in Western diets, is composed not only of protein, but also of fat, cholesterol, minerals and other nutrients. The amount of these nutrients including fatty acids may vary from one animal meat to the other. Previous studies in human have shown that consumption of skinless poultry, which is lower in cholesterol and saturated fat than many red meats, was not associated with the recurrence or progression of $\mathrm{PCa}$ [25]. However, consumption of baked poultry was inversely associated with advanced PCa [26,27], while cooked red meat was associated with increased advanced PCa risk $[26,27]$. Thus, how the food is prepared may modify its impact on PCa risk and progression. Overall, fish consumption may be associated with reduced PCa mortality, but high temperature cooked fish may contribute to PCa carcinogenesis [28]. Thus, it may be advisable to consume fish regularly but cooking temperature should be kept moderate.

\section{Dairy-based protein}

Another common protein source is dairy products, such as milk, cheese and yogurt. Previous studies have shown that dairy increased overall PCa risk but not with aggressive or lethal PCa $[29,30]$. In addition, both whole milk and low-fat milk consumption were reported to either promote or delay PCa progression [29,31]. In the Physicians Health follow up cohort with 21,660 men, total dairy consumption was found to be associated with increased PCa incidence [32]. In particular, low fat or skim milk increased low grade PCa, whereas whole milk increased fatal PCa risk. Though the exact component(s) of dairy products driving these associations is unknown, the high concentrations of saturated fat and calcium may be involved. A cross-sectional study of 1798 men showed that dairy protein was positively associated with serum IGF-1 [33] levels which may stimulate initiation or progression of PCa. Thus, further research is needed to clarify the relationship between dairy intake and PCa. There is insufficient data to provide recommendations specifically related to dairy or dairy protein and PCa risk or progression.

\section{Plant-based proteins}

Soy and soy-based products are rich in protein and phytoestrogens that may facilitate $\mathrm{PCa}$ prevention, but its role on PCa is unclear. In a study in mice, intake of soy products was associated with decreased hepatic aromatase, $5 \alpha$-reductase, expression of androgen receptor and its regulated genes, FOXA1, urogenital tract weight and $\mathrm{PCa}$ tumor progression [34]. A recent randomized trial of 177 men with high-risk disease after radical prostatectomy found that soy protein supplementation for two years had no effect on risk of PCa recurrence [35]. Although epidemiological and pre-clinical studies [36,37] support a potential role for soy/soy isoflavones in $\mathrm{PCa}$ risk reduction or progression, a meta-analysis did not find significant impact of soy intake in PSA levels, sex hormone-binding globulin, testosterone, free testosterone, estradiol or dihydrotestosterone [38]. Another RCT in patients before prostatectomy also did not find any effect of soy isoflavone supplement up to six weeks on PSA, serum total testosterone, free testosterone, total estrogen, estradiol or total cholesterol [39]. Since most RCTs 
conducted have been small and of short duration, further examination is needed.

Many studies have continued to examine the primary isoflavone in soy, genistein, and its effect on PCa. The potential for genistein to inihibit $\mathrm{PCa}$ cell detachment, invasion and metastasis is reported [40]. Genistein may modify glucose update and glucose transporter (GLUT) expression in $\mathrm{PCa}$ cells [41], or exert its anti-tumor effect by down regulating several microRNAs [42]. Studies using tumor cells and animal models suggest genistein may compete with and block endogenous estrogens from binding to the estrogen receptor, thereby inhibiting cellular proliferation, growth, and inducing differentiation and, specifically, genistein may inhibit cell detachment, protease production, cell invasion and thus prevent metastasis $[36,40,43]$. However, neither plasma nor urinary genistein levels were associated with PCa risk in case control studies [44,45]. In a phase 2 placebo-controlled RCT with 47 men, supplementation of $30 \mathrm{mg}$ genistein for three to six weeks significantly reduced androgen-related markers of PCa progression [46]. In addition, genistein may be beneficial in improving cabazitaxel chemotherapy in metastatic castration-resistant $\mathrm{PCa}$ [37]. Clinical studies are warranted to further examine the role of soy and soy isoflavones for PCa prevention or treatment. A definitive recommendation regarding protein intake for $\mathrm{PCa}$ prevention or treatment is not available yet.

\section{Fat}

Research findings examining fat consumption with $\mathrm{PCa}$ risk or progression are conflicting. Both the total absolute intake [47] of dietary fat and the relative fatty acid composition may independently relate to $\mathrm{PCa}$ initiation and/or progression. While animal studies repeatedly show that reducing dietary fat intake slows tumor growth [48-50] and high fat diets, especially animal fat and corn oil increase PCa progression [51], human data are less consistent. Case-control studies and cohort studies have shown either no association between total fat consumption and PCa risk [52-55] or an inverse association between fat intake and PCa survival, particularly among men with localized PCa [47]. In addition, a cross-sectional study showed that fat intake expressed as percent of total calorie intake was positively associated with PSA levels in 13,594 men without PCa [56].

Given these conflicting data, it is possible that the type of fatty acid [56] rather than total amount may play an important role in PCa development and progression. A study found plasma saturated fatty acids to be positively associated with $\mathrm{PCa}$ risk in a prospective cohort of 14,514 men of the Melbourne Collaborative Cohort Study [57]. In addition, another study found that eating more plant-based fat was associated with reduced PCa risk [58]. These studies support the current dietary guideline of eating less animal-based fat and more plant-based fat.

The data regarding omega- $6(\mathrm{w}-6)$ and omega-3 (w-3) polyunsaturated fatty acid (PUFA) consumption and PCa risk are also conflicting. While there are data to support a link between increased w-6 PUFA intake (mainly derived from corn oil) and risk of overall and high-grade PCa $[57,59]$, not all data support such a link [60]. In fact, a greater polyunsaturated fat intake was associated with a lower all cause mortality among men with nonmetastatic PCa in the Health Professionals Follow-up study [58]. The postulated mechanism linking w-6 PUFAs and PCa risk is the conversion of arachidonic acid (w-6 PUFA) to eicosanoids (prostaglandin E-2, hydroxyeicosatetraenoic acids and epoxyeicosatrienoic acids) leading to inflammation and cellular growth [61]. Conversely, w-3 PUFAs, which are found primarily in cold water oily fish, may slow growth of PCa through a number of mechanisms [61-63]. In a study of 48 men with low risk PCa under active surveillance, repeat biopsy in six months showed that prostate tissue $\mathrm{w}-3$ fatty acids, especially eicosapentaenoic acid (EPA), may protect against $\mathrm{PCa}$ progression [64]. In vitro and animal studies suggest that w-3 PUFAs induce anti-inflammatory, pro-apoptotic, antiproliferative and anti-angiogenic pathways $[65,66]$. Moreover, a mouse study comparing various types of fat found that only the fish oil diet (that is, omega-3 based diet) slowed PCa growth relative to other dietary fats [67]. In regards to human data, a phase II randomized trial showed that a low-fat diet with w-3 supplementation four to six weeks prior to radical prostatectomy decreased PCa proliferation and cell cycle progression (CCP) score $[62,68]$. A low-fat fish oil diet resulted in decreased 15(S)hydroxyeicosatetraenoic acid levels and lowered CCP score relative to a Western diet [69]. The potential benefits of omega- 3 fatty acids from fish are supported by epidemiological literature showing that $\mathrm{w}-3$ fatty acid intake was inversely associated with fatal PCa risk [70,71]. Despite the promise of omega-3 fatty acids, not all studies agree. Supplementing $2 \mathrm{~g}$ alpha-linolenic acid (ALA) per day for 40 months in 1,622 men with PSA $<4 \mathrm{ng} / \mathrm{ml}$ did not change their PSA [72]. However, another study found that a high blood serum n-3 PUFA and docosapentaenoic acid (DPA) was associated with reduced total PCa risk while high serum EPA and docosahexaenoic acid (DHA) was possibly associated with increased high-grade PCa risk [73]. Further research is required to understand better the role of omega-3 PUFAs in PCa prevention or treatment.

\section{Cholesterol}

Many pre-clinical studies have shown that the accumulation of cholesterol contributes to the progression of PCa [74-76]. It was suggested that a high cholesterol in 
circulation may be a risk factor for solid tumors, primarily through the upregulation of cholesterol synthesis, inflammatory pathways [77] and intratumoral steroidogenesis [78]. According to a recent study with 2,408 men scheduled for biopsy, serum cholesterol was independently associated with prediction of PCa risk [79]. Consistent with the cholesterol findings, usage of the cholesterol lowering drug statin post radical prostatectomy (RP) was significantly associated with reduced risk of biochemical recurrence in 1,146 radical prostatectomy patients [80]. Another study also showed that statins may reduce $\mathrm{PCa}$ risk by lowering progression [81]. Although the mechanism has not been established, more recent studies also showed that a low high-density lipoprotein (HDL) cholesterol level was associated with a higher risk for $\mathrm{PCa}$ and, thus, a higher HDL was protective [81-84]. These findings support the notion that a heart-healthy dietary intervention that lowers cholesterol may benefit prostate health also.

\section{Vitamins and minerals}

Herein we will review the recent data on vitamins A, B complex, $\mathrm{C}, \mathrm{D}, \mathrm{E}$, and $\mathrm{K}$ and selenium. In the two large clinical trials: the Carotene and Retinol Efficacy Trial (CARET; PCa was a secondary outcome) and the National Institutes of Health-American Association of Retired Persons (NIH-AARP) Diet and Health prospective cohort study, excessive multivitamin supplementation was associated with a higher risk of developing aggressive PCa, particularly among those taking individual $\beta$-carotene supplements $[85,86]$. Similarly, high serum $\beta$-carotene levels were associated with a higher risk for PCa among 997 Finnish men in the Kuopio Ischaemic Heart Disease Risk Factor cohort [87]. However, $\beta$-carotene supplement was not found to affect risk for lethal PCa during therapy [88], or in the Danish prospective cohort study of 26,856 men [89]. Circulating retinol also was not associated with $\mathrm{PCa}$ risk in a large case-control study [90]. Thus, the association between vitamin A and PCa is still unclear.

Preclinical evidence suggests folate depletion may slow tumor growth, while supplementation has no effect on growth or progression, but may directly lead to epigenetic changes via increases in DNA methylation [91]. Two meta-analyses also showed that circulating folate levels were positively associated with an increased risk of PCa $[92,93]$, while dietary or supplemental folate had no effect on PCa risk [94] in a cohort study with 58,279 men in the Netherlands [95] and a case-control study in Italy and Switzerland [96]. In fact, one study of a cohort of men undergoing radical prostatectomy at several Veterans Administration facilities across the US even showed that higher serum folate levels were associated with lower PSA and, thus, lower risk for biochemical failure [97]. Another study using data from the 2007 to 2010 National Health and Nutrition Examination Survey showed that a higher folate status may be protective against elevated PSA levels among 3,293 men, 40-years old and older, without diagnosed PCa [98]. It was suggested that folate may play a dual role in prostate carcinogenesis and, thus, the complex relationship between folate and PCa awaits further investigation [99].

Despite the potential role of vitamin C (ascorbic acid) as an antioxidant in anticancer therapy, trials examining dietary intake or supplementation of vitamin $\mathrm{C}$ are few. A RCT showed no effect of vitamin $\mathrm{C}$ intake on PCa risk [89]. Furthermore, vitamin $\mathrm{C}$ at high doses may act more as a pro-oxidant than antioxidant, complicating the research design and interpretation.

The primary active form of vitamin D, 1,25 dihydroxyvitamin D3 (calcitriol) aids in proper bone formation, induces differentiation of some immune cells, and inhibits pro-tumor pathways, such as proliferation and angiogenesis, and has been suggested to benefit PCa risk [100]; however, findings continue to be inconclusive. More recent studies found that increased serum vitamin D levels were associated with decreased PCa risk [101,102]. Further, supplementing vitamin D may slow $\mathrm{PCa}$ progression or induce apoptosis in PCa cells [103-105]. Other studies, however, reported either no impact of vitamin D supplement on PSA [106] or no effect of vitamin D status on PCa risk $[107,108]$. Some studies contrarily reported that a lower vitamin D status was associated with a lower PCa risk in older men [109], or a higher serum vitamin D was associated with a higher PCa risk $[110,111]$. A study even suggested that a ' $U$ ' shaped relationship may exist between vitamin D status and PCa and the optimal range of circulating vitamin $\mathrm{D}$ for PCa prevention may be narrow [112]. This is consistent with the findings for other nutrients that a greater intake of a favorable nutrient may not always be better.

A recent study showed that the association between vitamin D and PCa was modulated by vitamin D-binding protein [113] which may have partially explained the previous inconsistent findings. Further, a meta-analysis investigating the association between Vitamin $\mathrm{D}$ receptor (VDR) polymorphisms (BsmI and FokI) and PCa risk reported no relationship with PCa risk [114]. Thus, the role of vitamin D in PCa remains unclear.

In a large randomized trial with a total of 14,641 US male physicians $\geq 50$-years old, participants randomly received $400 \mathrm{IU}$ of vitamin $\mathrm{E}$ every other day for an overall mean of 10.3 (13.8) years. Vitamin E supplementation had no immediate or long-term effects on the risk of total cancers or PCa [115]. However, a moderate dose of vitamin E supplement (50 mg or about $75 \mathrm{IU}$ ) resulted in lower PCa risk among 29,133 Finnish male smokers [116]. Multiple preclinical studies suggest vitamin E slows tumor growth, partly due to inhibiting DNA synthesis and inducing 
apoptotic pathways [117]. Unfortunately, human studies have been less than supportive. Two observational studies (the Cancer Prevention Study II Nutrition Cohort and the NIH-AARP Diet and Health Study) both showed no association between vitamin E supplementation and PCa risk $[118,119]$. However, a higher serum $\alpha$-tocopherol but not the $\gamma$-tocopherol level was associated with decreased risk of PCa [120,121] and the association may be modified by genetic variations in vitamin E related genes [122]. On the contrary, a prospective randomized trial, the Selenium and Vitamin E Cancer Prevention Trial (SELECT), showed vitamin E supplementation significantly increased PCa risk [123] and that a higher plasma $\alpha$-tocopherol level may interact with selenium supplements to increase high grade PCa risk [124]. This finding is consistent with a case-cohort study of 1,739 cases and 3,117 controls that showed vitamin E increased PCa risk among those with low selenium status but not those with high selenium status [125]. Thus, more research is needed to examine the association between vitamin $\mathrm{E}$ and $\mathrm{PCa}$ and the dose effect and interaction with other nutrients should be considered.

Vitamin $\mathrm{K}$ has been hypothesized to help prevent $\mathrm{PCa}$ by reducing bioavailable calcium. Preclinical studies show the combination of vitamins $\mathrm{C}$ and $\mathrm{K}$ have potent antitumor activity in vitro and act as chemo- and radiosensitizers in vivo [126]. To date, few studies have investigated this, although one study using the European Prospective Investigation into Cancer and Nutrition (EPIC)-Heidelberg cohort found an inverse relationship between vitamin $\mathrm{K}$ (as menaquinones) intake and PCa incidence [127].

Little to no preclinical studies have been conducted to examine the role of calcium with PCa. Retrospective and meta-analyses suggest increased or reduced PCa risk with increased calcium intake, while others suggest no association $[128,129]$. Another study suggests a 'U'-shaped association, where very low calcium levels or supplementation are both associated with PCa [130].

Selenium, on the other hand, has been hypothesized to prevent PCa. While in vitro studies suggested that selenium inhibited angiogenesis and proliferation while inducing apoptosis [131], results from SELECT showed no benefit of selenium alone or in combination with vitamin E for PCa chemoprevention [123]. Further, selenium supplementation did not benefit men with low selenium status but increased the risk of high-grade PCa among men with high selenium status in a randomly selected cohort of 1,739 cases with high-grade (Gleason 7-10) PCa and 3,117 controls [125]. A prospective Netherlands Cohort Study, which included 58,279 men, 55- to 69-years old, also showed that toenail selenium was associated with a reduced risk of advanced PCa [132]. Further research is needed to clarify the role of selenium with PCa.

\section{Phytochemicals}

Along with vitamins and minerals [2], plants contain phytochemicals with potential anti-cancer effects. Typically not considered essential compounds, phytochemicals have antioxidant and anti-inflammatory properties.

Silibinin is a polyphenolic flavonoid found in the seeds of milk thistle. It has been shown in vitro and in vivo to inhihit PCa growth by targeting epidermal growth factor receptor (EGFR), IGF-1 receptor (IGF-1R), and nuclear factor-kappa B (NF-kB) pathways [133,134]. A recent study showed that silibinin may be useful in PCa prevention by inhibiting TGF $\beta 2$ expression and cancerassociated fibroblast (CAF)-like biomarkers in the human prostate stromal cells [135]. Thus, silibinin is a promising candidate as a PCa chemopreventive agent that awaits further research.

Curcumin is used as food additive in Asia and as an herbal medicine for inflammation [136]. In vitro, curcumin inhibits the pro-inflammatory protein NF- $\mathrm{KB}$ while inducing apoptosis through increased expression of proapoptotic genes [137]. In vivo, curcumin slows PCa growth in mice while sensitizing tumors to chemo- and radiotherapies [136]; however, no human trial has examined its impact on $\mathrm{PCa}$.

\section{Pomegranate}

The peel and fruit of pomegranates and walnuts are rich in ellagitannins (punicalagins). These phytochemicals are readily metabolized to the active form ellagic acid by gut flora [138]. Preclinical experiments show ellagitannins inhibit PCa proliferation and angiogenesis under hypoxic conditions and induce apoptosis $[137,138]$. In prospective trials in men with a rising PSA after primary treatment, pomegranate juice or POMx, a commercially available pomegranate extract, increased the PSA doubling time relative to baseline $[139,140]$, although no trials included a placebo group. Results are pending from a prospective placebo RCT using pomegranate extract in men with a rising PSA. However, in a placebo controlled trial, two pills of POMx daily for up to four weeks prior to radical prostatectomy had no impact on tumor pathology or oxidative stress or any other tumor measures [141].

\section{Green tea}

Green tea contains a number of antioxidant polyphenols including catechins, such as epigallocatechin gallate (EGCG), epigallocatechin (EGC), (-)-epicatechin-3-gallate (ECG) and (-)-epicatechin. Preclinical studies suggest EGCG inhibits PCa growth, induces intrinsic and extrinsic apoptotic pathways and decreases inflammation by inhibiting NFkB [137]. Furthermore, the antioxidant properties of EGCG are 25 to 100 times more potent than vitamins $C$ and $E$ [131]. In a prospective randomized preprostatectomy trial, men consuming brewed green tea 
prior to surgery had increased levels of green tea polyphenols in their prostate tissue [142]. In a small proof-ofprinciple trial with 60 men, daily supplementation of $600 \mathrm{mg}$ green tea catechin extract reduced PCa incidence by $90 \%$ (3\% versus $30 \%$ in the placebo group) [143]. Another small trial also showed that EGCG supplement resulted in a significant reduction in PSA, hepatocyte growth factor and vascular endothelial growth factor in men with $\mathrm{PCa}$ [144]. These studies suggest green tea polyphenols may lower $\mathrm{PCa}$ incidence and reduce $\mathrm{PCa}$ progression but more research is needed to confirm and clarify its mechanism $[137,143,145]$.

\section{Resveratrol}

While most in vitro studies suggest resveratrol inhibits PCa growth [146-148], resveratrol suppresses tumor growth in some [137] but not all animal models [149], possibly due to limited bioavailability $[150,151]$. To date, there are no clinical trials investigating the preventive or therapeutic effects of resveratrol on $\mathrm{PCa}$.

\section{Zyflamend}

Zyflamend is an anti-inflammatory mixture of herbs that has been shown to reduce PCa progression by lowering the expression of markers including pAKT, PSA, histone deacetylases and androgen receptor in animal models and PCa cell line [152-154]. Despite its anti-cancer potential [155], very few studies have been conducted in humans [156,157]. In an open-label Phase I trial of 23 patients with high-grade prostatic intraepithelial neoplasia, Zyflamend alone or in conjunction with other dietary supplements for 18 months reduced the risk for developing PCa [156]. More RCTs in humans are needed to confirm the efficacy and clinical application of this herbal supplement.

\section{Other whole foods \\ Fruits and vegetables}

Fruits and vegetables are rich sources of vitamins, minerals and phytochemicals. Several epidemiologic studies found inverse relationships between total fruit and vegetable intake [158], and cruciferous vegetable intake and PCa risk $[159,160]$. Allium vegetables, such as garlic, leeks, chives, and shallots, contain multiple sulfurous phytochemicals that were suggested to enhance the immune system, inhibit cell growth, modulate expression of androgen-responsive genes and induce apoptosis [161]. Although the number of published studies is limited, both preclinical and epidemiologic data suggest allium vegetable intake may be protective against $\mathrm{PCa}$, particularly localized disease [162]. A randomized trial with 199 men also found that a blend supplement of pomegranate, green tea, broccoli and turmeric significantly reduced the rate of rise in PSA in men with PCa [163].

\section{Tomatoes and tomato products}

A number of studies have examined the association between tomatoes and tomato products with $\mathrm{PCa}$ but the findings are inconclusive. The antioxidant lycopene, which is rich in tomatoes, has also been studied specifically for its impact on $\mathrm{PCa}$. In vitro, lycopene halts the cell cycle in several PCa cell lines and decreases IGF-1 signaling by inducing IGF-1 binding proteins [131]. While some animal studies found lycopene specifically slows PCa growth [164] or reduces PCa epithelial cells at stages of initiation, promotion and progression [165], two studies found conflicting findings between tomato paste and lycopene $[166,167]$. Prospective human studies found higher lycopene consumption [168,169] or higher serum levels were associated with lower PCa risk [170], but others have not $[171,172]$. Prostatic lycopene concentration below a $1 \mathrm{ng} / \mathrm{mg}$ threshold was associated with PCa at six-month follow-up biopsy $(P=0.003)$ [173]. Two short-term preprostatectomy trials using tomato sauce or lycopene supplementation demonstrated lycopene uptake in prostate tissue and antioxidant and potential anticancer effects [174,175]. While several clinical trials suggested an inverse relationship between lycopene supplementation, PSA levels and decreases in cancerrelated symptoms $[171,176]$, no large-scale randomized trials have tested the role of lycopene or tomato products on PCa prevention or treatment.

\section{Coffee}

Coffee contains caffeine and several unidentified phenolic compounds that may serve as antioxidants. Epidemiological studies suggest an inverse relationship between coffee consumption and PCa risk, mainly for advanced or lethal stage disease, and the findings were independent of caffeine content $[177,178]$. Although several epidemiological studies [179-182] found no association between coffee consumption and PCa risk, a recent meta-analysis of prospective studies concluded that coffee consumption may reduce PCa risk [183]. The potential mechanism(s) and pathway(s) involved are unknown but may include antioxidant, anti-inflammatory effects, glucose and insulin metabolism, and potential impact on IGF-I and circulating sex hormones.

\section{Dietary patterns}

Even though many single nutrients or food factors have been examined for their impact or association with $\mathrm{PCa}$ risk or progression, the results have largely been inconclusive. A potential reason for the inconsistency is the fact that the impact of single nutrient or food factor may be too small to be detected. In addition, nutrients naturally existing in foods often are highly correlated and may interact with each other and, thus, affect the impact on PCa. Thus, dietary pattern analysis has received an increasing 
interest but research has been limited and the existing results have been inconclusive. In a cohort of 293,464 men, a high dietary quality, as indicated by the Healthy Eating Index (HEI) score, was associated with a lower risk of total $\mathrm{PCa}$ risk [70]. The Mediterranean diet, which is high in vegetables, olive oil, complex carbohydrates, lean meats and antioxidants, is consistently recommended to patients for prevention of cardiovascular disease and obesity [184], and may show promise in PCa prevention [185]. Fish and omega-3 fatty acid consumption in the Mediterranean pattern were significantly and inversely associated with fatal PCa risk. In addition, adherence to the Mediterranean diet after diagnosis of non-metastatic PCa was associated with lower overall mortality [186]. Whereas, a Western pattern with high intakes of red meats, processed meats, fried fish, chips, high-fat milk and white bread, was associated with a higher risk for PCa [187].

Furthermore, Asian countries with high consumption of omega-3 PUFAs, soy and green tea-based phytochemicals, have lower PCa incidences versus countries consuming a 'Western-style' diet [188]. However, not all studies [189-191] supported an association between certain dietary pattern and risk of PCa. It is possible that the methodology used in identifying dietary patterns may not have captured all the dietary factors associated with PCa risk. Alternatively, each dietary pattern may contain both beneficial and harmful components resulting in an overall null association. More research is needed to continue searching for dietary patterns that combine most of the beneficial nutrients/food factors for $\mathrm{PCa}$ and limit most of the negative nutrients/ food factors.

\section{Future direction for clinical trials}

Based on the multitude of epidemiologic, preclinical and clinical trials described in this review, dietary interventions for the prevention and treatment of $\mathrm{PCa}$ hold great promise. In addition, several dietary factors and vitamins/supplements may be associated with PCa risk and/ or progression of disease. Prospective randomized trials are clearly indicated to identify specific nutrients or combination therapies for the prevention and treatment of PCa.

Recently, active surveillance (AS) has emerged as a viable option for men with lower risk PCa. Men on AS are motivated to adhere to diet and lifestyle modifications [192], making this subset a good target for dietary intervention and quality of life trials [193]. PCa survivors who are more active and report 'healthy' eating habits (that is, consuming low-fat, low-refined carbohydrate diets rich in fruits and vegetables) have better overall quality of life versus their inactive, unhealthy counterparts [194]. Thus, more randomized trials are warranted to determine the overall long-term effects of dietary intervention in this population. Specifically, key questions to address in future trials are: 1) Can dietary interventions delay the need for treatment in men on AS; 2) Can dietary interventions prevent recurrence for men after treatment; 3) Can dietary interventions delay progression among men with recurrent disease and, thus, delay the need for hormonal therapy; 4) Can dietary interventions reduce the side effects of PCa treatments including hormonal therapy and newer targeted therapies; and 5) Is there any role for dietary interventions alone or combined with targeted therapies in men on hormonal therapy to prevent castrate-resistance or after the emergence of castrate resistance disease? Because increasing evidence shows that metabolic abnormalities increase risk for $\mathrm{PCa}$, lifestyle intervention that improves metabolic profile is a win-win option for $\mathrm{PCa}$ prevention and treatment $[195,196]$.

\section{Conclusions}

Future research is required to determine the ideal diet for PCa prevention or treatment. However, several dietary factors and some dietary patterns hold promise in reducing PCa risk or progression and are consistent with current dietary guidelines for Americans [197]. For counseling patients on diet for primary and secondary $\mathrm{PCa}$ prevention, many believe 'heart healthy equals prostate healthy.' Thus, given the current inconclusive results, the best dietary advice for PCa prevention or management seems to include: increasing fruits and vegetables, replacing refined carbohydrates with whole grains, reducing total and saturated fat, reducing overcooked meats and consuming a moderate amount of calories or reducing carbohydrates with a primary goal of obtaining and maintaining a healthy body weight.

\section{Competing interests}

The authors declare that they have no competing interests.

\section{Authors' contributions}

P-HL and SF conducted the review, P-HL drafted the manuscript and SF and WA edited and provided critical input. All authors read and approved the final manuscript.

\section{Acknowledgements}

Funding was provided by grants 1K24CA160653 (Freedland), NIH P50CA92131 (W. Aronson). This manuscript is the result of work supported with resources and the use of facilities at the Veterans Administration Medical Center, West Los Angeles (W. Aronson)

\section{Author details}

${ }^{1}$ Department of Medicine, Division of Nephrology, Duke University Medical Center, Box 3487, Durham, NC 27710, USA. ²Urology Section, Department of Surgery, Veterans Affairs Greater Los Angeles Healthcare System, Los Angeles, CA, USA. ${ }^{3}$ Department of Urology, UCLA School of Medicine, Los Angeles, CA, USA. ${ }^{4}$ Urology Section, Department of Surgery, Durham Veterans Affairs Medical Center, Division of Urology, Durham, NC, USA. ${ }^{5}$ Duke Prostate Center, Departments of Surgery and Pathology, Duke University Medical Center, Durham, NC, USA.

Received: 4 August 2014 Accepted: 11 November 2014

Published online: 08 January 2015 


\section{References}

1. Center MM, Jemal A, Lortet-Tieulent J, Ward E, Ferlay J, Brawley O, Bray F International variation in prostate cancer incidence and mortality rates. Eur Urol 2012, 61:1079-1092.

2. Masko EM, Allott EH, Freedland SJ: The relationship between nutrition and prostate cancer: is more always better? Eur Urol 2013, 63:810-820.

3. Mavropoulos JC, Isaacs WB, Pizzo SV, Freedland SJ: Is there a role for a low-carbohydrate ketogenic diet in the management of prostate cancer? Urology 2006, 68:15-18.

4. Freedland SJ, Mavropoulos J, Wang A, Darshan M, Demark-Wahnefried W, Aronson WJ, Cohen P, Hwang D, Peterson B, Fields T, Pizzo SV, Isaacs WB: Carbohydrate restriction, prostate cancer growth, and the insulin-like growth factor axis. Prostate 2008, 68:11-19.

5. Mavropoulos JC: Buschemeyer WC 3rd, Tewari AK, Rokhfeld D, Pollak M, Zhao Y, Febbo PG, Cohen P, Hwang D, Devi G, Demark-Wahnefried W, Westman EC, Peterson BL, Pizzo SV, Freedland SJ: The effects of varying dietary carbohydrate and fat content on survival in a murine LNCaP prostate cancer xenograft model. Cancer Prev Res (Phila Pa) 2009, 2:557-565.

6. Masko EM, Thomas JA 2nd, Antonelli JA, Lloyd JC, Phillips TE, Poulton SH, Dewhirst MW, Pizzo SV, Freedland SJ: Low-carbohydrate diets and prostate cancer: how low is "low enough"? Cancer Prev Res (Phila) 2010, 3:1124-1131.

7. Drake I, Sonestedt E, Gullberg B, Ahlgren G, Bjartell A, Wallstrom P, Wirfält E: Dietary intakes of carbohydrates in relation to prostate cancer risk: a prospective study in the Malmo Diet and Cancer cohort. Am J Clin Nutr 2012, 96:1409-1418.

8. Zhang J, Shen C, Wang L, Ma Q, Xia P, Qi M, Yang M, Han B: Metformin inhibits epithelial-mesenchymal transition in prostate cancer cells: Involvement of the tumor suppressor miR30a and its target gene SOX4. Biochem Biophys Res Commun 2014, 452:746-752.

9. Lee SY, Song CH, Xie YB, Jung C, Choi HS, Lee K: SMILE upregulated by metformin inhibits the function of androgen receptor in prostate cancer cells. Cancer Lett 2014, 354:390-397.

10. Demir U, Koehler A, Schneider R, Schweiger S, Klocker H: Metformin antitumor effect via disruption of the MID1 translational regulator complex and AR downregulation in prostate cancer cells. BMC Cancer 2014, 14:52.

11. Margel D: Metformin to prevent prostate cancer: a call to unite. Eur Urol 2014. doi:10.1016/j.eururo.2014.05.012. [Epub ahead of time]

12. Margel D, Urbach DR, Lipscombe LL, Bell CM, Kulkarni G, Austin PC, Fleshner $\mathrm{N}$ : Metformin use and all-cause and prostate cancer-specific mortality among men with diabetes. J Clin Oncol 2013, 31:3069-3075.

13. Tseng $\mathrm{CH}$ : Metformin significantly reduces incident prostate cancer risk in Taiwanese men with type 2 diabetes mellitus. Eur J Cancer 2014, 50:2831-2837

14. Joshua AM, Zannella VE, Downes MR, Bowes B, Hersey K, Koritzinsky M, Schwab M, Hofmann U, Evans A, van der Kwast T, Trachtenberg J, Finelli A, Fleshner N, Sweet J, Pollak M: A pilot 'window of opportunity' neoadjuvant study of metformin in localised prostate cancer. Prostate Cancer Prostatic Dis 2014, 17:252-258.

15. Rothermundt C, Hayoz S, Templeton AJ, Winterhalder R, Strebel RT, Bartschi D, Pollak M, Lui L, Endt K, Schiess R, Rüschoff JH, Cathomas R, Gillessen S: Metformin in Chemotherapy-naive Castration-resistant Prostate Cancer: A Multicenter Phase 2 Trial (SAKK 08/09). Eur Urol 2014, 66:468-474.

16. Allott EH, Abern MR, Gerber L, Keto CJ, Aronson WJ, Terris MK, Kane CJ, Amling CL, Cooperberg MR, Moorman PG, Freedland SJ: Metformin does not affect risk of biochemical recurrence following radical prostatectomy: results from the SEARCH database. Prostate Cancer Prostatic Dis 2013, 16:391-397.

17. Rieken M, Kluth LA, Xylinas E, Fajkovic H, Becker A, Karakiewicz PI, Herman M, Lotan Y, Seitz C, Schramek P, Remzi M, Loidl W, Pummer K, Lee RK, Faison T, Scherr DS, Kautzky-Willer A, Bachmann A, Tewari A, Shariat SF: Association of diabetes mellitus and metformin use with biochemical recurrence in patients treated with radical prostatectomy for prostate cancer. World J Urol 2014, 32:999-1005.

18. Margel D, Urbach D, Lipscombe LL, Bell CM, Kulkarni G, Austin PC, Fleshne $\mathrm{N}$ : Association between metformin use and risk of prostate cancer and its grade. J Natl Cancer Inst 2013, 105:1123-1131.

19. Franciosi M, Lucisano G, Lapice E, Strippoli GF, Pellegrini F, Nicolucci A: Metformin therapy and risk of cancer in patients with type 2 diabetes: systematic review. PLoS One 2013, 8:e71583.
20. Kaushik D, Karnes RJ, Eisenberg MS, Rangel L, Carlson RE, Bergstralh EJ: Effect of metformin on prostate cancer outcomes after radical prostatectomy. Urol Oncol 2014, 32:43 e41-47.

21. Bensimon L, Yin H, Suissa S, Pollak MN, Azoulay L: The use of metformin in patients with prostate cancer and the risk of death. Cancer Epidemiol Biomarkers Prev 2014, 23:2111-2118.

22. Tsilidis KK, Capothanassi D, Allen NE, Rizos EC, Lopez DS, van Veldhoven K, Sacerdote C, Ashby D, Vineis P, Tzoulaki I, loannidis JP: Metformin does not affect cancer risk: a cohort study in the U.K. Clinical Practice Research Datalink analyzed like an intention-to-treat trial. Diabetes Care 2014, 37:2522-2532

23. Levine ME, Suarez JA, Brandhorst S, Balasubramanian P, Cheng CW, Madia F, Fontana L, Mirisola MG, Guevara-Aguirre J, Wan J, Passarino G, Kennedy BK, Wei M, Cohen P, Crimmins EM, Longo VD: Low protein intake is associated with a major reduction in IGF-1, cancer, and overall mortality in the 65 and younger but not older population. Cell Metab 2014, 19:407-417.

24. Solon-Biet SM, MCMahon AC, Ballard JW, Ruohonen K, Wu LE, Cogger VC, Warren A, Huang X, Pichaud N, Melvin RG, Gokarn R, Khalil M, Turner N, Cooney GJ, Sinclair DA, Raubenheimer D, Le Couteur DG, Simpson SJ: The ratio of macronutrients, not caloric intake, dictates cardiometabolic health, aging, and longevity in ad libitum-fed mice. Cell Metab 2014 19:418-430

25. Richman EL, Stampfer MJ, Paciorek A, Broering JM, Carroll PR, Chan JM: Intakes of meat, fish, poultry, and eggs and risk of prostate cancer progression. Am J Clin Nutr 2010, 91:712-721.

26. Joshi AD, John EM, Koo J, Ingles SA, Stern MC: Fish intake, cooking practices, and risk of prostate cancer: results from a multi-ethnic case-control study. Cancer Causes Control 2012, 23:405-420.

27. Joshi AD, Corral R, Catsburg C, Lewinger JP, Koo J, John EM, Ingles SA, Stern MC: Red meat and poultry, cooking practices, genetic susceptibility and risk of prostate cancer: results from a multiethnic case-control study. Carcinogenesis 2012, 33:2108-2118.

28. Catsburg C, Joshi AD, Corral R, Lewinger JP, Koo J, John EM, Ingles SA, Stern MC: Polymorphisms in carcinogen metabolism enzymes, fish intake, and risk of prostate cancer. Carcinogenesis 2012, 33:1352-1359.

29. Pettersson A, Kasperzyk JL, Kenfield SA, Richman EL, Chan JM, Willett WC, Stampfer MJ, Mucci LA, Giovannucci EL: Milk and dairy consumption among men with prostate cancer and risk of metastases and prostate cancer death. Cancer Epidemiol Biomarkers Prev 2012, 21:428-436.

30. Deneo-Pellegrini H, Ronco AL, De Stefani E, Boffetta P, Correa P, Mendilaharsu M, Acosta G: Food groups and risk of prostate cancer: a case-control study in Uruguay. Cancer Causes Control 2012, 23:1031-1038.

31. Park SY, Murphy SP, Wilkens LR, Stram DO, Henderson BE, Kolonel LN: Calcium, vitamin $\mathrm{D}$, and dairy product intake and prostate cancer risk: the Multiethnic Cohort Study. Am J Epidemiol 2007, 166:1259-1269.

32. Song Y, Chavarro JE, Cao Y, Qiu W, Mucci L, Sesso HD, Stampfer MJ, Giovannucci E, Pollak M, Liu S, Ma J: Whole milk intake is associated with prostate cancer-specific mortality among U.S. male physicians. I Nutr Feb 2013, 143:189-196

33. Young NJ, Metcalfe C, Gunnell D, Rowlands MA, Lane JA, Gillbert R, Avery KN, Davis M, Neal DE, Hamdy FC, Donovan J, Martin RM, Holly JM: A crosssectional analysis of the association between diet and insulin-like growth factor (IGF)-I, IGF-II, IGF-binding protein (IGFBP)-2, and IGFBP-3 in men in the United Kingdom. Cancer Causes Control 2012, 23:907-917.

34. Christensen MJ, Quiner TE, Nakken HL, Lephart ED, Eggett DL, Urie PM: Combination effects of dietary soy and methylselenocysteine in a mouse model of prostate cancer. Prostate 2013, 73:986-995.

35. Bosland MC, Kato I, Zeleniuch-Jacquotte A, Schmoll J, Enk Rueter E, Melamed J, Kong MX, Macias V, Kajdacsy-Balla A, Lumey LH, Xie H, Gao W, Walden P, Lepor H, Taneja SS, Randolph C, Schlicht MJ, Meserve-Watanabe $H$, Deaton RJ, Davies JA: Effect of soy protein isolate supplementation on biochemical recurrence of prostate cancer after radical prostatectomy: a randomized trial. JAMA 2013, 310:170-178.

36. Chiyomaru T, Yamamura S, Fukuhara S, Yoshino H, Kinoshita T, Majid S, Saini S, Chang I, Tanaka Y, Enokida H, Seki N, Nakagawa M, Dahiya R: Genistein inhibits prostate cancer cell growth by targeting miR-34a and oncogenic HOTAIR. PLoS One 2013, 8:e70372.

37. Zhang S, Wang Y, Chen Z, Kim S, lqbal S, Chi A, Ritenour C, Wang YA, Kucuk O, Wu D: Genistein enhances the efficacy of cabazitaxel chemotherapy in metastatic castration-resistant prostate cancer cells. Prostate 2013, 73:1681-1689. 
38. van Die MD, Bone KM, Williams SG, Pirotta MV: Soy and soy isoflavones in prostate cancer: a systematic review and meta-analysis of randomized controlled trials. BJU Int 2014, 113:E119-E130.

39. Hamilton-Reeves JM, Banerjee S, Banerjee SK, Holzbeierlein JM, Thrasher JB, Kambhampati S, Keighley J, Van Veldhuizen P: Short-term soy isoflavone intervention in patients with localized prostate cancer: a randomized, double-blind, placebo-controlled trial. PLoS One 2013, 8:e68331.

40. Pavese JM, Krishna SN, Bergan RC: Genistein inhibits human prostate cancer cell detachment, invasion, and metastasis. Am J Clin Nutr 2014, 100:431S-436S.

41. Gonzalez-Menendez P, Hevia D, Rodriguez-Garcia A, Mayo JC, Sainz RM: Regulation of GLUT transporters by flavonoids in androgen-sensitive and -insensitive prostate cancer cells. Endocrinology 2014, 155:3238-3250.

42. Hirata H, Hinoda Y, Shahryari V, Deng G, Tanaka Y, Tabatabai ZL, Dahiya R: Genistein downregulates onco-miR-1260b and upregulates sFRP1 and Smad4 via demethylation and histone modification in prostate cancer cells. Br J Cancer 2014, 110:1645-1654.

43. Handayani R, Rice L, Cui Y, Medrano TA, Samedi VG, Baker HV, Szabo NJ, Shiverick KT: Soy isoflavones alter expression of genes associated with cancer progression, including interleukin-8, in androgen-independent PC-3 human prostate cancer cells. J Nutr 2006, 136:75-82.

44. Travis RC, Allen NE, Appleby PN, Price A, Kaaks R, Chang-Claude J, Boeing H, Aleksandrova K, Tiønneland A, Johnsen NF, Overvad K, Ramón Quirós J, González CA, Molina-Montes E, Sánchez MJ, Larrañaga N, Castaño JM, Ardanaz E, Khaw KT, Wareham N, Trichopoulou A, Karapetyan T, Rafnsson SB, Palli D, Krogh V, Tumino R, Vineis P, Bueno-de-Mesquita HB, Stattin P, Johansson $M$, et al: Prediagnostic concentrations of plasma genistein and prostate cancer risk in 1,605 men with prostate cancer and 1,697 matched control participants in EPIC. Cancer Causes Control 2012, 23:1163-1171.

45. Jackson MD, McFarlane-Anderson ND, Simon GA, Bennett FI, Walker SP: Urinary phytoestrogens and risk of prostate cancer in Jamaican men. Cancer Causes Control 2010, 21:2249-2257.

46. Lazarevic B, Hammarström C, Yang J, Ramberg H, Diep LM, Karlsen SJ, Kucuk O, Saatcioglu F, Taskèn KA, Svindland A: The effects of short-term genistein intervention on prostate biomarker expression in patients with localised prostate cancer before radical prostatectomy. Br J Nutr 2012, 108:2138-2147.

47. Epstein MM, Kasperzyk JL, Mucci LA, Giovannucci E, Price A, Wolk A, Håkansson N, Fall K, Andersson SO, Andrén O: Dietary fatty acid intake and prostate cancer survival in Orebro County, Sweden. Am J Epidemiol 2012, 176:240-252.

48. Kobayashi N, Barnard RJ, Said J, Hong-Gonzalez J, Corman DM, Ku M, Doan NB, Gui D, Elashoff D, Cohen P, Aronson WJ: Effect of low-fat diet on development of prostate cancer and Akt phosphorylation in the Hi-Myc transgenic mouse model. Cancer Res 2008, 68:3066-3073.

49. Ngo TH, Barnard RJ, Cohen P, Freedland S, Tran C, deGregorio F, Elshimali $\mathrm{Yl}$, Heber D, Aronson WJ: Effect of isocaloric low-fat diet on human LAPC-4 prostate cancer xenografts in severe combined immunodeficient mice and the insulin-like growth factor axis. Clin Cancer Res 2003, 9:2734-2743.

50. Huang M, Narita S, Numakura K, Tsuruta H, Saito M, Inoue T, Horikawa $Y$, Tsuchiya N, Habuchi T: A high-fat diet enhances proliferation of prostate cancer cells and activates MCP-1/CCR2 signaling. Prostate 2012, 72:1779-1788

51. Chang SN, Han J, Abdelkader TS, Kim TH, Lee JM, Song J, Kim KS, Park JH, Park JH: High animal fat intake enhances prostate cancer progression and reduces glutathione peroxidase 3 expression in early stages of TRAMP mice. Prostate 2014, 74:1266-1277.

52. Bidoli E, Talamini R, Bosetti C, Negri E, Maruzzi D, Montella M, Franceschi S, La Vecchia C: Macronutrients, fatty acids, cholesterol and prostate cancer risk. Ann Oncol 2005, 16:152-157.

53. Park SY, Murphy SP, Wilkens LR, Henderson BE, Kolonel LN: Fat and meat intake and prostate cancer risk: the multiethnic cohort study. Int J Cancer 2007, 121:1339-1345.

54. Wallstrom P, Bjartell A, Gullberg B, Olsson H, Wirfalt E: A prospective study on dietary fat and incidence of prostate cancer (Malmo, Sweden). Cancer Causes Control 2007, 18:1107-1121.

55. Crowe FL, Key TJ, Appleby PN, Travis RC, Overvad K, Jakobsen MU, Johnsen NF, Tjønneland A, Linseisen J, Rohrmann S, Boeing H, Pischon T, Trichopoulou A, Lagiou P, Trichopoulos D, Sacerdote C, Palli D, Tumino R,
Krogh V, Bueno-de-Mesquita HB, Kiemeney LA, Chirlaque MD, Ardanaz E, Sánchez MJ, Larrañaga N, González CA, Quirós JR, Manjer J, Wirfält E, Stattin $P$, et al: Dietary fat intake and risk of prostate cancer in the European Prospective Investigation into Cancer and Nutrition. Am J Clin Nutr 2008, 87:1405-1413.

56. Ohwaki K, Endo F, Kachi Y, Hattori K, Muraishi O, Nishikitani M, Yano E: Relationship between dietary factors and prostate-specific antigen in healthy men. Urol Int 2012, 89:270-274

57. Bassett JK, Severi G, Hodge AM, Maclnnis RJ, Gibson RA, Hopper JL, English DR, Giles GG: Plasma phospholipid fatty acids, dietary fatty acids and prostate cancer risk. Int J Cancer 2013, 133:1882-1891.

58. Richman EL, Kenfield SA, Chavarro JE, Stampfer MJ, Giovannucci EL, Willett WC, Chan JM: Fat intake after diagnosis and risk of lethal prostate cancer and all-cause mortality. JAMA Intern Med 2013, 173:1318-1326.

59. Williams CD, Whitley BM, Hoyo C, Grant DJ, Iraggi JD, Newman KA, Gerber L, Taylor LA, McKeever MG, Freedland SJ: A high ratio of dietary $n-6 / n-3$ polyunsaturated fatty acids is associated with increased risk of prostate cancer. Nutr Res 2011, 31:1-8.

60. Chua ME, Sio MC, Sorongon MC, Dy JS: Relationship of dietary intake of omega- 3 and omega- 6 fatty acids with risk of prostate cancer development: a meta-analysis of prospective studies and review of literature. Prostate Cancer 2012, 2012:826254.

61. Berquin IM, Edwards IJ, Kridel SJ, Chen YQ: Polyunsaturated fatty acid metabolism in prostate cancer. Cancer Metastasis Rev 2011, 30:295-309.

62. Aronson WJ, Kobayashi N, Barnard RJ, Henning S, Huang M, Jardack PM, Liu B, Gray A, Wan J, Konijeti R, Freedland SJ, Castor B, Heber D, Elashoff D, Said J, Cohen P, Galet C: Phase II prospective randomized trial of a low-fat diet with fish oil supplementation in men undergoing radical prostatectomy. Cancer Prev Res (Phila) 2011, 4:2062-2071.

63. Hughes-Fulford M, Li CF, Boonyaratanakornkit J, Sayyah S: Arachidonic acid activates phosphatidylinositol 3-kinase signaling and induces gene expression in prostate cancer. Cancer Res 2006, 66:1427-1433.

64. Moreel X, Allaire J, Leger C, Caron A, Labonte ME, Lamarche B, Julien P, Desmeules P, Têtu B, Fradet V: Prostatic and dietary omega-3 fatty acids and prostate cancer progression during active surveillance. Cancer Prev Res (Phila) 2014, 7:766-776.

65. Spencer L, Mann C, Metcalfe M, Webb M, Pollard C, Spencer D, Berry D, Steward W, Dennison A: The effect of omega-3 FAs on tumour angiogenesis and their therapeutic potential. Eur J Cancer 2009, 45:2077-2086.

66. Gu Z, Suburu J, Chen H, Chen YQ: Mechanisms of omega-3 polyunsaturated fatty acids in prostate cancer prevention. Biomed Res Int 2013, 2013:824563.

67. Lloyd JC, Masko EM, Wu C, Keenan MM, Pilla DM, Aronson WJ, Chi JT, Freedland SJ: Fish oil slows prostate cancer xenograft growth relative to other dietary fats and is associated with decreased mitochondrial and insulin pathway gene expression. Prostate Cancer Prostatic Dis 2013, 16:285-291.

68. Williams CM, Burdge G: Long-chain n-3 PUFA: plant v. marine sources. Proc Nutr Soc 2006, 65:42-50.

69. Galet C, Gollapudi K, Stepanian S, Byrd JB, Henning SM, Grogan T, Elashoff D, Heber D, Said J, Cohen P, Aronson WJ: Effect of a low-fat fish oil diet on proinflammatory eicosanoids and cell-cycle progression score in men undergoing radical prostatectomy. Cancer Prev Res (Phila) 2014, 7:97-104.

70. Bosire C, Stampfer MJ, Subar AF, Park Y, Kirkpatrick SI, Chiuve SE, Hollenbeck $A R$, Reedy J: Index-based dietary patterns and the risk of prostate cancer in the NIH-AARP diet and health study. Am J Epidemiol 2013, 177:504-513.

71. Aronson WJ, Barnard RJ, Freedland SJ, Henning S, Elashoff D, Jardack PM, Cohen P, Heber D, Kobayashi N: Growth inhibitory effect of low fat diet on prostate cancer cells: results of a prospective, randomized dietary intervention trial in men with prostate cancer. J Urol 2010, 183:345-350.

72. Brouwer IA, Geleijnse JM, Klaasen VM, Smit LA, Giltay EJ, de Goede J, Heijboer AC, Kromhout D, Katan MB: Effect of alpha linolenic acid supplementation on serum prostate specific antigen (PSA): results from the alpha omega trial. PLOS One 2013, 8:e81519.

73. Chua ME, Sio MC, Sorongon MC, Morales ML Jr: The relevance of serum levels of long chain omega-3 polyunsaturated fatty acids and prostate cancer risk: A meta-analysis. Can Urol Assoc J 2013, 7:E333-E343.

74. Yue S, Li J, Lee SY, Lee HJ, Shao T, Song B, Cheng L, Masterson TA, Liu X, Ratliff TL, Cheng JX: Cholesteryl ester accumulation induced by PTEN loss and PI3K/AKT activation underlies human prostate cancer aggressiveness. Cell Metab 2014, 19:393-406. 
75. Sun Y, Sukumaran P, Varma A, Derry S, Sahmoun AE, Singh BB: Cholesterolinduced activation of TRPM7 regulates cell proliferation, migration, and viability of human prostate cells. Biochim Biophys Acta 1843, 2014:1839-1850

76. Murai T: Cholesterol lowering: role in cancer prevention and treatment. Biol Chem 2014. doi:10.1515/hsz-2014-0194. [Epub ahead of time]

77. Zhuang L, Kim J, Adam RM, Solomon KR, Freeman MR: Cholesterol targeting alters lipid raft composition and cell survival in prostate cancer cells and xenografts. J Clin Invest 2005, 115:959-968.

78. Mostaghel EA, Solomon KR, Pelton K, Freeman MR, Montgomery RB: Impact of circulating cholesterol levels on growth and intratumoral androgen concentration of prostate tumors. PLoS One 2012, 7:e30062.

79. Morote J, Celma A, Planas J, Placer J, de Torres I, Olivan M, Carles J, Reventós J, Doll A: Role of serum cholesterol and statin use in the risk of prostate cancer detection and tumor aggressiveness. Int J Mol Sci 2014, 15:13615-13623.

80. Allott EH, Howard LE, Cooperberg MR, Kane CJ, Aronson WJ, Terris MK, Amling CL, Freedland SJ: Postoperative statin use and risk of biochemical recurrence following radical prostatectomy: results from the Shared Equal Access Regional Cancer Hospital (SEARCH) database. BJU Int 2014, 114:661-666.

81. Jespersen CG, Norgaard M, Friis S, Skriver C, Borre M: Statin use and risk of prostate cancer: A Danish population-based case-control study, 1997-2010. Cancer Epidemiol 2014, 38:42-47.

82. Meyers CD, Kashyap ML: Pharmacologic elevation of high-density lipoproteins: recent insights on mechanism of action and atherosclerosis protection. Curr Opin Cardiol 2004, 19:366-373.

83. Xia P, Vadas MA, Rye KA, Barter PJ, Gamble JR: High density lipoprotein (HDL) interrupt the sphingosine kinase signaling pathway. A possible mechanism for protection against atherosclerosis by HDL.J Biol Chem 1999, 274:33143-33147.

84. Kotani K, Sekine Y, Ishikawa S, Ikpot IZ, Suzuki K, Remaley AT: High-density lipoprotein and prostate cancer: an overview. J Epidemio/ 2013, 23:313-319.

85. Soni MG, Thurmond TS, Miller ER 3rd, Spriggs T, Bendich A, Omaye ST: Safety of vitamins and minerals: controversies and perspective. Toxicol Sci 2010, 118:348-355.

86. Neuhouser ML, Barnett MJ, Kristal AR, Ambrosone CB, King I, Thornquist M, Goodman G: (n-6) PUFA increase and dairy foods decrease prostate cancer risk in heavy smokers. J Nutr 2007, 137:1821-1827.

87. Karppi J, Kurl S, Laukkanen JA, Kauhanen J: Serum beta-carotene in relation to risk of prostate cancer: the Kuopio Ischaemic Heart Disease Risk Factor study. Nutr Cancer 2012, 64:361-367.

88. Margalit DN, Kasperzyk JL, Martin NE, Sesso HD, Gaziano JM, Ma J, Stampfer MJ, Mucci LA: Beta-carotene antioxidant use during radiation therapy and prostate cancer outcome in the Physicians' Health Study. Int J Radiat Oncol Biol Phys 2012, 83:28-32.

89. Roswall N, Larsen SB, Friis S, Outzen M, Olsen A, Christensen J, Dragsted LO, Tjønneland A: Micronutrient intake and risk of prostate cancer in a cohort of middle-aged, Danish men. Cancer Causes Control 2013, 24:1129-1135

90. Gilbert R, Metcalfe C, Fraser WD, Donovan J, Hamdy F, Neal DE, Lane JA, Martin RM: Associations of circulating retinol, vitamin E, and 1,25dihydroxyvitamin D with prostate cancer diagnosis, stage, and grade. Cancer Causes Control 2012, 23:1865-1873.

91. Bistulfi G, Foster BA, Karasik E, Gillard B, Miecznikowski J, Dhiman VK, Smiraglia DJ: Dietary folate deficiency blocks prostate cancer progression in the TRAMP model. Cancer Prev Res (Phila) 2011, 4:1825-1834

92. Collin SM: Folate and B12 in prostate cancer. Adv Clin Chem 2013, 60:1-63.

93. Tio M, Andrici J, Cox MR, Eslick GD: Folate intake and the risk of prostate cancer: a systematic review and meta-analysis. Prostate Cancer Prostatic Dis 2014, 17:213-219.

94. Vollset SE, Clarke R, Lewington S, Ebbing M, Halsey J, Lonn E, Armitage J, Manson JE, Hankey GJ, Spence JD, Galan P, Bønaa KH, Jamison R, Gaziano JM, Guarino P, Baron JA, Logan RF, Giovannucci EL, den Heijer M, Ueland PM, Bennett D, Collins R, Peto R, B-Vitamin Treatment Trialists' Collaboration: Effects of folic acid supplementation on overall and site-specific cancer incidence during the randomised trials: meta-analyses of data on 50,000 individuals. Lancet 2013, 381:1029-1036.
95. Verhage BA, Cremers P, Schouten LJ, Goldbohm RA, van den Brandt PA: Dietary folate and folate vitamers and the risk of prostate cancer in The Netherlands Cohort Study. Cancer Causes Control 2012, 23:2003-2011.

96. Tavani A, Malerba S, Pelucchi C, Dal Maso L, Zucchetto A, Serraino D, Levi F, Montella M, Franceschi S, Zambon A, La Vecchia C: Dietary folates and cancer risk in a network of case-control studies. Ann Oncol 2012, 23:2737-2742.

97. Moreira DM, Banez LL, Presti JC Jr, Aronson WJ, Terris MK, Kane CJ, Amling $C L$, Freedland $\mathrm{SJ}$ : High serum folate is associated with reduced biochemical recurrence after radical prostatectomy: results from the SEARCH Database. Int Braz J Urol 2013, 39:312-318. discussion 319.

98. Han YY, Song JY, Talbott EO: Serum folate and prostate-specific antigen in the United States. Cancer Causes Control 2013, 24:1595-1604.

99. Rycyna KJ, Bacich DJ, O'Keefe DS: Opposing roles of folate in prostate cancer. Urology 2013, 82:1197-1203.

100. Gilbert R, Martin RM, Beynon R, Harris R, Savovic J, Zuccolo L, Bekkering GE, Fraser WD, Sterne JA, Metcalfe: Associations of circulating and dietary vitamin D with prostate cancer risk: a systematic review and doseresponse meta-analysis. Cancer Causes Control 2011, 22:319-340.

101. Schenk JM, Till CA, Tangen CM, Goodman PJ, Song X, Torkko KC, Kristal AR, Peters U, Neuhouser ML: Serum 25-hydroxyvitamin d concentrations and risk of prostate cancer: results from the Prostate Cancer Prevention Trial. Cancer Epidemiol Biomarkers Prev 2014, 23:1484-1493.

102. Schwartz GG: Vitamin D, in blood and risk of prostate cancer: lessons from the Selenium and Vitamin E Cancer Prevention Trial and the Prostate Cancer Prevention Trial. Cancer Epidemiol Biomarkers Prev 2014, 23:1447-1449.

103. Giangreco AA, Vaishnav A, Wagner D, Finelli A, Fleshner N, Van der Kwast T, Vieth R, Nonn L: Tumor suppressor microRNAs, miR-100 and $-125 \mathrm{~b}$, are regulated by 1,25 -dihydroxyvitamin $D$ in primary prostate cells and in patient tissue. Cancer Prev Res (Phila) 2013, 6:483-494.

104. Hollis BW, Marshall DT, Savage SJ, Garrett-Mayer E, Kindy MS, Gattoni-Celli S: Vitamin D3 supplementation, low-risk prostate cancer, and health disparities. J Steroid Biochem Mol Biol 2013, 136:233-237.

105. Sha J, Pan J, Ping P, Xuan H, Li D, Bo J, Liu D, Huang Y: Synergistic effect and mechanism of vitamin $A$ and vitamin $D$ on inducing apoptosis of prostate cancer cells. Mol Biol Rep 2013, 40:2763-2768.

106. Chandler PD, Giovannucci EL, Scott JB, Bennett GG, Ng K, Chan AT, Hollis BW, Emmons KM, Fuchs CS, Drake BF: Null association between Vitamin D and PSA levels among black men in a Vitamin D supplementation trial. Cancer Epidemiol Biomarkers Prev 2014, 23:1944-1947.

107. Skaaby T, Husemoen LL, Thuesen BH, Pisinger C, Jorgensen T, Roswall N, Larsen SC, Linneberg A: Prospective population-based study of the association between serum 25-hydroxyvitamin-D levels and the incidence of specific types of cancer. Cancer Epidemiol Biomarkers Prev 2014, 23:1220-1229.

108. Holt SK, Kolb S, Fu R, Horst R, Feng Z, Stanford JL: Circulating levels of 25-hydroxyvitamin $\mathrm{D}$ and prostate cancer prognosis. Cancer Epidemiol 2013, 37:666-670.

109. Wong YY, Hyde Z, McCaul KA, Yeap BB, Golledge J, Hankey GJ, Flicker L: In older men, lower plasma 25-hydroxyvitamin $D$ is associated with reduced incidence of prostate, but not colorectal or lung cancer. PLoS One 2014, 9:e99954.

110. Xu Y, Shao X, Yao Y, Xu L, Chang L, Jiang Z, Lin Z: Positive association between circulating 25 -hydroxyvitamin $D$ levels and prostate cancer risk: new findings from an updated meta-analysis. J Cancer Res Clin Oncol 2014, 140:1465-1477.

111. Meyer HE, Robsahm TE, Bjorge T, Brustad M, Blomhoff R: Vitamin D, season, and risk of prostate cancer: a nested case-control study within Norwegian health studies. Am J Clin Nutr 2013, 97:147-154.

112. Kristal AR, Till C, Song X, Tangen CM, Goodman PJ, Neuhauser ML, Schenk JM, Thompson IM, Meyskens FL Jr, Goodman GE, Minasian LM, Parnes HL, Klein EA: Plasma vitamin D and prostate cancer risk: results from the Selenium and Vitamin E Cancer Prevention Trial. Cancer Epidemiol Biomarkers Prev 2014, 23:1494-1504.

113. Weinstein SJ, Mondul AM, Kopp W, Rager H, Virtamo J, Albanes D: Circulating 25-hydroxyvitamin D, vitamin D-binding protein and risk of prostate cancer. Int J Cancer 2013, 132:2940-2947.

114. Guo Z, Wen J, Kan Q, Huang S, Liu X, Sun N, Li Z: Lack of association between vitamin $\mathrm{D}$ receptor gene Fokl and Bsml polymorphisms and 
prostate cancer risk: an updated meta-analysis involving 21,756 subjects. Tumour Biol 2013, 34:3189-3200.

115. Wang L, Sesso HD, Glynn RJ, Christen WG, Bubes V, Manson JE, Buring JE, Gaziano JM: Vitamin E and C supplementation and risk of cancer in men: posttrial follow-up in the Physicians' Health Study II randomized trial. Am J Clin Nutr 2014, 100:915-923.

116. Virtamo J, Taylor PR, Kontto J, Mannisto S, Utriainen M, Weinstein SJ, Huttunen J, Albanes D: Effects of alpha-tocopherol and beta-carotene supplementation on cancer incidence and mortality: 18-year postintervention follow-up of the Alpha-tocopherol, Beta-carotene Cancer Prevention Study. Int J Cancer 2014, 135:178-185.

117. Basu A, Imrhan V: Vitamin E and prostate cancer: is vitamin E succinate a superior chemopreventive agent? Nutr Rev 2005, 63:247-251.

118. Lawson KA, Wright ME, Subar A, Mouw T, Hollenbeck A, Schatzkin A Leitzmann MF: Multivitamin use and risk of prostate cancer in the National Institutes of Health-AARP Diet and Health Study. J Nat/ Cancer Inst 2007, 99:754-764.

119. Calle EE, Rodriguez C, Jacobs EJ, Almon ML, Chao A, McCullough ML, Feigelson HS, Thun MJ: The American Cancer Society Cancer Prevention Study II Nutrition Cohort: rationale, study design, and baseline characteristics. Cancer 2002, 94:2490-2501.

120. Weinstein SJ, Peters U, Ahn J, Friesen MD, Riboli E, Hayes RB, Albanes D: Serum alpha-tocopherol and gamma-tocopherol concentrations and prostate cancer risk in the PLCO Screening Trial: a nested case-control study. PLoS One 2012, 7:e40204.

121. Cui R, Liu ZQ, Xu Q: Blood alpha-tocopherol, gamma-tocopherol levels and risk of prostate cancer: a meta-analysis of prospective studies. PLoS One 2014, 9:e93044.

122. Major JM, Yu K, Weinstein SJ, Berndt SI, Hyland PL, Yeager M, Chanock S, Albanes D: Genetic variants reflecting higher vitamin e status in men are associated with reduced risk of prostate cancer. J Nutr May 2014, 144:729-733.

123. Klein EA, Thompson IM Jr, Tangen CM, Crowley JJ, Lucia MS, Goodman PJ, Minasian LM, Ford LG, Parnes HL, Gaziano JM, Karp DD, Lieber MM, Walther PJ, Klotz L, Parsons JK, Chin JL, Darke AK, Lippman SM, Goodman GE, Meyskens FL Jr, Baker LH: Vitamin E and the risk of prostate cancer: the Selenium and Vitamin E Cancer Prevention Trial (SELECT). JAMA 2011, 306:1549-1556.

124. Albanes D, Till C, Klein EA, Goodman PJ, Mondul AM, Weinstein SJ, aylor PR, Parnes HL, Gaziano JM, Song X, Fleshner NE, Brown PH, Meyskens FL Jr, Thompson IM: Plasma tocopherols and risk of prostate cancer in the Selenium and Vitamin E Cancer Prevention Trial (SELECT). Cancer Prev Res (Phila) 2014, 7:886-895.

125. Kristal AR, Darke AK, Morris JS, Tangen CM, Goodman PJ, Thompson IM, Meyskens FL Jr, Goodman GE, Minasian LM, Parnes HL, Lippman SM, Klein EA: Baseline selenium status and effects of selenium and vitamin e supplementation on prostate cancer risk. J Natl Cancer Inst 2014, 106:djt456.

126. Jamison JM, Gilloteaux J, Taper HS, Summers JL: Evaluation of the in vitro and in vivo antitumor activities of vitamin $\mathrm{C}$ and $\mathrm{K}-3$ combinations against human prostate cancer. J Nutr 2001, 131:158S-160S.

127. Nimptsch K, Rohrmann S, Kaaks R, Linseisen J: Dietary vitamin K intake in relation to cancer incidence and mortality: results from the Heidelberg cohort of the European Prospective Investigation into Cancer and Nutrition (EPIC-Heidelberg). Am J Clin Nutr 2010, 91:1348-1358.

128. Ma RW, Chapman K: A systematic review of the effect of diet in prostate cancer prevention and treatment. J Hum Nutr Diet 2009, 22:187-199. quiz 200-182.

129. Bristow SM, Bolland MJ, MacLennan GS, Avenell A, Grey A, Gamble GD, Reid IR: Calcium supplements and cancer risk: a meta-analysis of randomised controlled trials. Br J Nutr 2013, 110:1384-1393.

130. Williams CD, Whitley BM, Hoyo C, Grant DJ, Schwartz GG, Presti JC Jr, Iraggi JD, Newman KA, Gerber L, Taylor LA, McKeever MG, Freedland SJ: Dietary calcium and risk for prostate cancer: a case-control study among US veterans. Prev Chronic Dis 2012, 9:E39.

131. Hori S, Butler E, McLoughlin J: Prostate cancer and diet: food for thought? BJU Int 2011, 107:1348-1359.

132. Geybels MS, Verhage BA, van Schooten FJ, Goldbohm RA, van den Brandt PA: Advanced prostate cancer risk in relation to toenail selenium levels. J Natl Cancer Inst 2013, 105:1394-1401.
133. Singh RP, Agarwal R: Prostate cancer chemoprevention by silibinin: bench to bedside. Mol Carcinog 2006, 45:436-442.

134. Ting H, Deep G, Agarwal R: Molecular mechanisms of silibinin-mediated cancer chemoprevention with major emphasis on prostate cancer. AAPS J 2013, 15:707-716

135. Ting HJ, Deep G, Jain AK, Cimic A, Sirintrapun J, Romero LM, Cramer SD, Agarwal C, Agarwal R: Silibinin prevents prostate cancer cell-mediated differentiation of naive fibroblasts into cancer-associated fibroblast phenotype by targeting TGF beta2. Mol Carcinog 2014. doi:10.1002/ mc.22135. [Epub ahead of time]

136. Goel A, Aggarwal BB: Curcumin, the golden spice from Indian saffron, is a chemosensitizer and radiosensitizer for tumors and chemoprotector and radioprotector for normal organs. Nutr Cancer 2010, 62:919-930.

137. Khan N, Adhami VM, Mukhtar H: Apoptosis by dietary agents for prevention and treatment of prostate cancer. Endocr Relat Cancer 2010, 17:R39-R52.

138. Heber D: Pomegranate ellagitannins. In Herbal Medicine: Biomolecular and Clinical Aspects. 2nd edition. Edited by Benzie IF, Wachtel-Galor S. Boca Raton, FL: CRC Press; 2011.

139. Pantuck AJ, Leppert JT, Zomorodian N, Aronson W, Hong J, Barnard RJ Seeram N, Liker H, Wang H, Elashoff R, Heber D, Aviram M, Ignarro L, Belldegrun A: Phase II study of pomegranate juice for men with rising prostate-specific antigen following surgery or radiation for prostate cancer. Clin Cancer Res 2006, 12:4018-4026.

140. Paller CJ, Ye X, Wozniak PJ, Gillespie BK, Sieber PR, Greengold RH, Stockton $B R$, Hertzman BL, Efros MD, Roper RP, Liker HR, Carducci MA: A randomized phase II study of pomegranate extract for men with rising PSA following initial therapy for localized prostate cancer. Prostate Cancer Prostatic Dis 2013, 16:50-55.

141. Freedland SJ, Carducci M, Kroeger N, Partin A, Rao JY, Jin Y, Kerkoutian S, Wu H, Li Y, Creel P, Mundy K, Gurganus R, Fedor H, King SA, Zhang Y, Heber D, Pantuck AJ: A double-blind, randomized, neoadjuvant study of the tissue effects of POMx pills in men with prostate cancer before radical prostatectomy. Cancer Prev Res (Phila) 2013, 6:1120-1127.

142. Wang P, Aronson WJ, Huang M, Zhang Y, Lee RP, Heber D, Henning SM: Green tea polyphenols and metabolites in prostatectomy tissue: implications for cancer prevention. Cancer Prev Res (Phila) 2010, 3:985-993.

143. Kurahashi N, Sasazuki S, Iwasaki M, Inoue M, Tsugane S: Green tea consumption and prostate cancer risk in Japanese men: a prospective study. Am J Epidemiol 2008, 167:71-77.

144. McLarty J, Bigelow RL, Smith M, Elmajian D, Ankem M, Cardelli JA: Tea polyphenols decrease serum levels of prostate-specific antigen, hepatocyte growth factor, and vascular endothelial growth factor in prostate cancer patients and inhibit production of hepatocyte growth factor and vascular endothelial growth factor in vitro. Cancer Prev Res (Phila) 2009, 2:673-682

145. Bettuzzi S, Brausi M, Rizzi F, Castagnetti G, Peracchia G, Corti A Chemoprevention of human prostate cancer by oral administration of green tea catechins in volunteers with high-grade prostate intraepithelial neoplasia: a preliminary report from a one-year proof-of-principle study. Cancer Res 2006, 66:1234-1240.

146. Fraser SP, Peters A, Fleming-Jones S, Mukhey D, Djamgoz MB: Resveratrol: inhibitory effects on metastatic cell behaviors and voltage-gated $\mathrm{Na}^{(+)}$ channel activity in rat prostate cancer in vitro. Nutr Cancer 2014, 66:1047-1058.

147. Oskarsson A, Spatafora C, Tringali C, Andersson AO: Inhibition of CYP17A1 activity by resveratrol, piceatannol, and synthetic resveratrol analogs. Prostate 2014, 74:839-851.

148. Ferruelo A, Romero I, Cabrera PM, Arance I, Andres G, Angulo JC: Effects of resveratrol and other wine polyphenols on the proliferation, apoptosis and androgen receptor expression in LNCaP cells. Actas Urol Esp Jul-Aug 2014, 38:397-404.

149. Osmond GW, Masko EM, Tyler DS, Freedland SJ, Pizzo S: In vitro and in vivo evaluation of resveratrol and 3,5-dihydroxy-4'-acetoxy-trans-stilbene in the treatment of human prostate carcinoma and melanoma. J Surg Res 2013, 179:e141-e148.

150. Baur JA, Sinclair DA: Therapeutic potential of resveratrol: the in vivo evidence. Nat Rev Drug Discov 2006, 5:493-506.

151. Klink JC, Tewari AK, Masko EM, Antonelli J, Febbo PG, Cohen P, Dewhirst MW, Pizzo SV, Freedland SJ: Resveratrol worsens survival in SCID mice 
with prostate cancer xenografts in a cell-line specific manner, through paradoxical effects on oncogenic pathways. Prostate 2013, 73:754-762.

152. Huang EC, Zhao Y, Chen G, Baek SJ, McEntee MF, Minkin S, Biggerstaff JP, Whelan J: Zyflamend, a polyherbal mixture, down regulates class I and class II histone deacetylases and increases p21 levels in castrate-resistant prostate cancer cells. BMC Complement Altern Med 2014, 14:68.

153. Huang EC, McEntee MF, Whelan J: Zyflamend, a combination of herbal extracts, attenuates tumor growth in murine xenograft models of prostate cancer. Nutr Cancer 2012, 64:749-760.

154. Yan J, Xie B, Capodice JL, Katz AE: Zyflamend inhibits the expression and function of androgen receptor and acts synergistically with bicalutimide to inhibit prostate cancer cell growth. Prostate 2012, 72:244-252.

155. Kunnumakkara AB, Sung B, Ravindran J, Diagaradjane P, Deorukhkar A, Dey S, Koca C, Tong Z, Gelovani JG, Guha S, Krishnan S, Aggarwal BB: Zyflamend suppresses growth and sensitizes human pancreatic tumors to gemcitabine in an orthotopic mouse model through modulation of multiple targets. Int J Cancer 2012, 131:E292-E303.

156. Capodice JL, Gorroochurn P, Cammack AS, Eric G, McKiernan JM, Benson MC, Stone BA, Katz AE: Zyflamend in men with high-grade prostatic intraepithelial neoplasia: results of a phase I clinical trial. J Soc Integr Oncol 2009, 7:43-51

157. Rafailov S, Cammack S, Stone BA, Katz AE: The role of Zyflamend, an herbal anti-inflammatory, as a potential chemopreventive agent against prostate cancer: a case report. Integr Cancer Ther 2007, 6:74-76.

158. Askari F, Parizi MK, Jessri M, Rashidkhani B: Fruit and vegetable intake in relation to prostate cancer in Iranian men: a case-control study. Asian Pac J Cancer Prev 2014, 15:5223-5227.

159. Liu B, Mao Q, Cao M, Xie L: Cruciferous vegetables intake and risk of prostate cancer: a meta-analysis. Int J Urol 2012, 19:134-141.

160. Richman EL, Carroll PR, Chan JM: Vegetable and fruit intake after diagnosis and risk of prostate cancer progression. Int J Cancer 2012, 131:201-210.

161. Hsing AW, Chokkalingam AP, Gao YT, Madigan MP, Deng J, Gridley G, Fraumeni JF Jr: Allium vegetables and risk of prostate cancer: a population-based study. J Natl Cancer Inst 2002, 94:1648-1651.

162. Chan R, Lok K, Woo J: Prostate cancer and vegetable consumption. Mol Nutr Food Res 2009, 53:201-216.

163. Thomas R, Williams M, Sharma H, Chaudry A, Bellamy P: A double-blind, placebo-controlled randomised trial evaluating the effect of a polyphenol-rich whole food supplement on PSA progression in men with prostate cancer-the UK NCRN Pomi-T study. Prostate Cancer Prostatic Dis 2014, 17:180-186.

164. Yang CM, Lu IH, Chen HY, Hu ML: Lycopene inhibits the proliferation of androgen-dependent human prostate tumor cells through activation of PPARgamma-LXRalpha-ABCA1 pathway. J Nutr Biochem 2012, 23:8-17.

165. Qiu X, Yuan Y, Vaishnav A, Tessel MA, Nonn L, van Breemen RB: Effects of lycopene on protein expression in human primary prostatic epithelial cells. Cancer Prev Res (Phila) 2013, 6:419-427.

166. Boileau TW, Liao Z, Kim S, Lemeshow S, Erdman JW Jr, Clinton SK: Prostate carcinogenesis in $\mathrm{N}$-methyl-N-nitrosourea (NMU)-testosterone-treated rats fed tomato powder, lycopene, or energy-restricted diets. $J$ Natl Cancer Inst 2003, 95:1578-1586.

167. Konijeti R, Henning S, Moro A, Sheikh A, Elashoff D, Shapiro A, Ku M, Said JW, Heber D, Cohen P, Aronson WJ: Chemoprevention of prostate cancer with lycopene in the TRAMP model. Prostate 2010, 70:1547-1554.

168. Giovannucci E, Rimm EB, Liu Y, Stampfer MJ, Willett WC: A prospective study of tomato products, lycopene, and prostate cancer risk. J Natl Cancer Inst 2002, 94:391-398.

169. Zu K, Mucci L, Rosner BA, Clinton SK, Loda M, Stampfer MJ, Giovannucci E: Dietary lycopene, angiogenesis, and prostate cancer: a prospective study in the prostate-specific antigen era. J Natl Cancer Inst 2014, 106:djt430.

170. Gann PH, Ma J, Giovannucci E, Willett W, Sacks FM, Hennekens CH, Stampfer MJ: Lower prostate cancer risk in men with elevated plasma lycopene levels: results of a prospective analysis. Cancer Res 1999, 59:1225-1230.

171. Kristal AR, Till C, Platz EA, Song X, King IB, Neuhouser ML, Ambrosone CB, Thompson IM: Serum lycopene concentration and prostate cancer risk: results from the Prostate Cancer Prevention Trial. Cancer Epidemiol Biomarkers Prev 2011, 20:638-646.

172. Kirsh VA, Mayne ST, Peters U, Chatterjee N, Leitzmann MF, Dixon LB, Urban DA, Crawford ED, Hayes RB: A prospective study of lycopene and tomato product intake and risk of prostate cancer. Cancer Epidemiol Biomarkers Prev 2006, 15:92-98.

173. Mariani S, Lionetto L, Cavallari M, Tubaro A, Rasio D, De Nunzio C, Hong GM, Borro M, Simmaco M: Low prostate concentration of lycopene is associated with development of prostate cancer in patients with highgrade prostatic intraepithelial neoplasia. Int J Mo/ Sci 2014, 15:1433-1440

174. Kucuk O, Sarkar FH, Djuric Z, Sakr W, Pollak MN, Khachik F, Banerjee M, Bertram JS, Wood DP Jr: Effects of lycopene supplementation in patients with localized prostate cancer. Exp Biol Med (Maywood) 2002, 227:881-885.

175. Chen L, Stacewicz-Sapuntzakis M, Duncan C, Sharifi R, Ghosh L, van Breemen $R$, Ashton D, Bowen PE: Oxidative DNA damage in prostate cancer patients consuming tomato sauce-based entrees as a whole-food intervention. J Natl Cancer Inst 2001, 93:1872-1879.

176. van Breemen RB, Sharifi R, Viana M, Pajkovic N, Zhu D, Yuan L, Yang Y, Bowen PE, Stacewicz-Sapuntzakis M: Antioxidant effects of lycopene in African American men with prostate cancer or benign prostate hyperplasia: a randomized, controlled trial. Cancer Prev Res (Phila) 2011, 4:711-718.

177. Shafique K, McLoone P, Qureshi K, Leung H, Hart C, Morrison DS: Coffee consumption and prostate cancer risk: further evidence for inverse relationship. Nutr J 2012, 11:42.

178. Wilson KM, Kasperzyk JL, Rider JR, Kenfield S, van Dam RM, Stampfer MJ, Giovannucci E, Mucci LA: Coffee consumption and prostate cancer risk and progression in the Health Professionals Follow-up Study. J Natl Cancer Inst 2011, 103:876-884.

179. Bosire C, Stampfer MJ, Subar AF, Wilson KM, Park Y, Sinha R: Coffee consumption and the risk of overall and fatal prostate cancer in the NIH-AARP Diet and Health Study. Cancer Causes Control 2013, 24:1527-1534.

180. Arab L, Su LJ, Steck SE, Ang A, Fontham ET, Bensen JT, Mohler JL: Coffee consumption and prostate cancer aggressiveness among African and Caucasian Americans in a population-based study. Nutr Cancer 2012, 64:637-642.

181. Phillips RL, Snowdon DA: Association of meat and coffee use with cancers of the large bowel, breast, and prostate among Seventh-Day Adventists: preliminary results. Cancer Res 1983, 43:2403 s-2408s.

182. Hsing AW, McLaughlin JK, Schuman LM, Bjelke E, Gridley G, Wacholder S, Chien HT, Blot WJ: Diet, tobacco use, and fatal prostate cancer: results from the Lutheran Brotherhood Cohort Study. Cancer Res 1990, 50:6836-6840

183. Cao S, Liu L, Yin X, Wang Y, Liu J, Lu Z: Coffee consumption and risk of prostate cancer: a meta-analysis of prospective cohort studies. Carcinogenesis 2014, 35:256-261.

184. Nordmann AJ, Suter-Zimmermann K, Bucher HC, Shai I, Tuttle KR, Estruch R, Briel M: Meta-analysis comparing Mediterranean to low-fat diets for modification of cardiovascular risk factors. Am J Med 2011, 124:841-851. e842.

185. Kapiszewska M: A vegetable to meat consumption ratio as a relevant factor determining cancer preventive diet. The Mediterranean versus other European countries. Forum Nutr 2006, 59:130-153.

186. Kenfield SA, Dupre N, Richman EL, Stampfer MJ, Chan JM, Giovannucci EL: Mediterranean diet and prostate cancer risk and mortality in the Health Professionals Follow-up Study. Eur Urol 2014, 65:887-894.

187. Ambrosini GL, Fritschi L, de Klerk NH, Mackerras D, Leavy J: Dietary patterns identified using factor analysis and prostate cancer risk: a case control study in Western Australia. Ann Epidemiol 2008, 18:364-370.

188. Baade PD, Youlden DR, Krnjacki LJ: International epidemiology of prostate cancer: geographical distribution and secular trends. Mol Nutr Food Res 2009, 53:171-184.

189. Muller DC, Severi G, Baglietto L, Krishnan K, English DR, Hopper JL, Giles GG: Dietary patterns and prostate cancer risk. Cancer Epidemiol Biomarkers Prev 2009, 18:3126-3129.

190. Tseng M, Breslow RA, DeVellis RF, Ziegler RG: Dietary patterns and prostate cancer risk in the National Health and Nutrition Examination Survey Epidemiological Follow-up Study cohort. Cancer Epidemiol Biomarkers Prev 2004, 13:71-77.

191. Wu K, Hu FB, Willett WC, Giovannucci E: Dietary patterns and risk of prostate cancer in U.S. men. Cancer Epidemiol Biomarkers Prev 2006, 15:167-171

192. Daubenmier JJ, Weidner G, Marlin R, Crutchfield L, Dunn-Emke S, Chi C, Gao B, Carroll P, Ornish D: Lifestyle and health-related quality of life of men with prostate cancer managed with active surveillance. Urology 2006, 67:125-130. 
193. Parsons JK, Newman VA, Mohler JL, Pierce JP, Flatt S, Marshall J: Dietary modification in patients with prostate cancer on active surveillance: a randomized, multicentre feasibility study. BJU Int 2008, 101:1227-1231.

194. Mosher CE, Sloane R, Morey MC, Snyder DC, Cohen HJ, Miller PE,

Demark-Wahnefried W: Associations between lifestyle factors and quality of life among older long-term breast, prostate, and colorectal cancer survivors. Cancer 2009, 115:4001-4009.

195. Bhindi B, Locke J, Alibhai SM, Kulkarni GS, Margel DS, Hamilton RJ, Finelli A Trachtenberg J, Zlotta AR, Toi A, Hersey KM, Evans A, van der Kwast TH, Fleshner NE: Dissecting the association between metabolic syndrome and prostate cancer risk: analysis of a large clinical cohort. Eur Urol 2014 doi:10.1016/j.eururo.2014.01.040. [Epub ahead of time]

196. Esposito K, Chiodini P, Capuano A, Bellastella G, Maiorino MI, Parretta E, Lenzi A, Giugliano D: Effect of metabolic syndrome and its components on prostate cancer risk: meta-analysis. J Endocrinol Invest 2013, 36:132-139

197. U.S. Department of Agriculture and U.S. Department of Health and Human Services. Dietary Guidelines for Americans, 2010. 7th edition. Washington, DC: U.S. Government Printing Office, December, 2010.

\section{Submit your next manuscript to BioMed Central and take full advantage of:}

- Convenient online submission

- Thorough peer review

- No space constraints or color figure charges

- Immediate publication on acceptance

- Inclusion in PubMed, CAS, Scopus and Google Scholar

- Research which is freely available for redistribution 